Available online:

http://journal.imla.or.id/index.php/arabi

IMLA

Arabi : Journal of Arabic Studies, 2 (1), 2017, 19-36

DOI: http://dx.doi.org/10.24865/ajas.v2i1.31

\title{
PETA PERKEMBANGAN LEKSIKOGRAFI ARAB DI INDONESIA: STUDI KRITIS ATAS KAMUS KARYA MAHMUD YUNUS
}

\author{
Muhbib Abdul Wahab \\ Universitas Islam Negeri Syarif Hidayatullah Jakarta \\ E-mail : muhbib@uinjkt.ac.id
}

\begin{abstract}
This critical study is aimed to explain the position of Arabic-Indonesian dictionary (the work of Mahmud Yunus) in the mapping of Arabic lexicography development in Indonesia. This study was carried out through bibliographical based qualitative with the work of Mahmud Yunus as the main source. The results indicate that Mahmud Yunus Dictionary is categorized into bilingual dictionary following the sarfi alifbai system, in which the entry and vocabulary are systemized alphabetically. The display of the dictionary is a bland of common dictionary and pictorial dictionary, because the dictionary is provided with pictures adapted from al-Munjid. The critical and substantive evaluation study show that the compiling process of the dictionary is not fully based on lexicology and modern linguistics. Some mistakes (such as printing, diction, meaning, and entry), pictures, and classic illustrations, and some involvement of the ammiyyah vocabularies should be revised and contextualized in accordance to the development of science and technology. This study need to be developed to make the dictionary contribute the development of Arabic language teaching.
\end{abstract}

Keywords: the mapping of Arabic lexicography, Mahmud Yunus dictionary, lexicographical criticism

\begin{abstract}
Abstrak
Studi kritis ini bertujuan menjelaskan posisi kamus Arab-Indonesia karya Mahmud Yunus dalam peta perkembangan leksikografi Arab di Indonesia. Studi ini menggunakan pendekatan kualitatif berbasis data bibliografis yang sumber utamanya adalah karya Mahmud Yunus tersebut. Hasil kajian ini menunjukkan bahwa posisi Kamus Mahmud Yunus (KMY) termasuk kategori kamus dwibahasa yang menganut sistem șarfi alifbai, entri dan kosakata bersistematika alfabetis. Tampilan isi kamus ini memperlihatkan perpaduan antara kamus umum dengan kamus bergambar, karena kamus dilengkapi dengan gambar-gambar yang "disadur" dari al-Munjid. Studi kritis dan evaluasi substantif menunjukkan bahwa penyusunan KMY belum sepenuhnya berbasis leksikologi dan linguistik modern. Berbagai kesalahan (cetak, pemilihan diksi arti, urutan entri), gambar dan ilustrasi yang sudah menjadi "klasik", dan masuknya sejumlah kosakata 'āmmiyyah perlu direvisi dan dikontekstualisasikan dengan perkembangan ilmu pengetahuan, teknologi. Hal ini penting dikembangkan agar dunia perkamusan Arab-Indonesia dan sebaliknya berkontribusi penting dalam pengembangan pembelajaran bahasa Arab di masa depan.
\end{abstract}

Kata Kunci: peta leksikografi Arab, kamus Mahmud Yunus, kritik leksikografis 


\section{Arabi : Journal of Arabic Studies}

\section{Pendahuluan}

Salah satu karya leksikografis Mahmud Yunus (1898-1982) yang paling populer adalah Kamus Arab-Indonesia (Qämūs Arabī Indunīsī). Kamus ini merupakan kamus "klasik" yang tergolong laku di pasaran dan terus mengalami cetak ulang. Hingga Kamus ini tidak hanya dipakai di kalangan siswa-siswi madrasah dan pesantren, tetapi juga paling banyak dibawa masuk kelas oleh mahasiswa di perguruan tinggi. Dari segi ukuran dan harganya, kamus ini tergolong tidak terlalu besar dan tidak mahal. Barangkali faktor ekonomis dan praktis inilah yang menjadi penyebab kamus ini tetap bisa "bertahan dan mampu bersaing" dengan kemunculan berbagai kamus yang lebih baru dan kontemporer. Misalnya saja, Kamus Arab-Indonesia al-Munawwir (1984) karya Ahmad Warson Munawwir, Kamus Modern Arab-Indonesia al-Kamal (2010) karya Kaserun AS. Rahman dan diedit oleh Nur Mufid, Kamus Besar Bahasa Arab untuk Pelajar, Mahasiswa, dan Umum (2013) karya Amalia Hasanah, Kamus Kontemporer Arab-Indonesia (1996) karya Atabik Ali dan Ahmad Zuhdi Muhdlor, Kamus Arab-Indonesia al-Bisri (1999) karya Adib Bisri dan Munawar AF., Kamus Kontekstual Arab-Indonesia (2001) karya Basuni Imamuddin dan Nashiroh Ishaq, dan KABA: Kamus Akbar Bahasa Arab (Arab-Indonesia) (2013) karya A. Thaha Husein Almujahid dan A. Atho'illah Fathoni Alkhalil.

Kamus pertama yang dimiliki oleh penulis sebagai mahasiswa Jurusan Pendidikan Bahasa Arab (1987) Fakultas Tarbiyah IAIN Syarif Hidayatullah Jakarta adalah kamus Arab-Indonesia karya Mahmud Yunus tersebut. Kesan pertama saat itu adalah bahwa kamus ini cukup bisa melayani kebutuhan mahasiswa. Namun seiring dengan banyaknya kamus baru yang diterbitkan, eksistensi Kamus Mahmud Yunus (selanjutnya disebut: KMY) menjadi menarik untuk dikritisi dan dikomparasikan dengan kamus lain, misalnya Mu'jam al-Lughah al- 'Arabiyyah al-Mu'āshirah (1985) karya Hans Wehr dan al-Mu’jam al-Wasìth (1972) karya Ibrāhīm Anīs, dkk.

Hingga saat ini KMY sudah mengalami cetak ulang lebih dari 10 kali, dan hampir dapat dipastikan merupakan kamus paling banyak dipakai oleh kalangan siswa, mahasiswa dan guru, bahkan dosen bahasa Arab di seluruh Indonesia. Hasil penelitian Saidun Fiddaroini (2009), dkk, menunjukkan bahwa kamus al-Kalali (Indonesia-Arab), al-Bisyri (Arab-Indonesia), al-Munawwir (Arab-(Indonesia) dan Mahmud Yunus (Arab-Indonesia) dinilai sering "menyesatkan" penggunanya dalam bidang linguistik. Karena keempat kamus tersebut disusun oleh penulis yang pandai berbahasa Arab, tetapi bukan linguis yang handal. Namun demikian, kamus-kamus tersebut belum tertandingi oleh kamus sejenis lainnya (Saidun Fiddaraini, 2016).

Penelitian R. Taufiqurrochman (2014), Tashrîf al-Ma'äjim al-'Arabiyyah wa Tathwïruhā fi Indonesia menjelaskan bahwa peta leksikografi Arab-Indonesia menunjukkan adanya dua jenis kamus, yaitu mu'jam al-alfäh dan mu'jam al-ma'āni. Keduanya dapat dikategorikan sebagai kamus bahasa dan terjemah, baik dwibahasa maupun multibahasa. Kamus dimaksud mempunyai beragam pendekatan: tematik, bergambar, bahasa dan terjemahannya. Tampilan dan ukurannya bervariasi: kamus saku, kamus, kamus singkat, kamus sedang, dan kamus besar. Kamus terbesar karena KABA (Kamus Akbar Bahasa Arab) belum beredar luas pada 2014 — yang dipetakan peneliti adalah al-Munawwir, karena memuat 87.234 entri kata dan derivasinya. Penelitian ini tidak mengkritisi konten dan konteks penggunaan kamus yang ada, termasuk kamus Mahmud Yunus.

Penelitian tentang kamus Arab-Indonesia karya Mahmud Yunus, secara spesifik pernah dilakukan oleh Rina Hutari (2011) dengan topik Manhaj Kitābah Qāmūs Arabì Indunīsì li Mahmud Yunus: Dirāsah Tahliliyyah Washfiyyah. Penelitian ini berkesimpulan bahwa kamus Mahmud Yunus disusun dengan metode sharaf dengan sistematika berdasarkan akar kata dan urutan alfabetis (alifbāì). Akan tetapi, sistematika entri (madākhil) dalam kamus ini menunjukkan sejumlah inkonsistensi, karena terdapat beberapa entri yang disusun berdasarkan urutan fonetik (bunyi), bukan berdasarkan asal-usul derivasi (ashl al-isytiqāq).

Perdebatan akademik seputar leksikografi KMY menjadi menarik, jika dikaitkan dengan pemaknaan entri dan kata yang dimuat di dalamnya. Menurut pembacaan penulis, sejak 
diterbitkan pertama kali pada tahun 1973 hingga sekarang -edisi terbarunya diterbitkan oleh Pustaka Ilmu dengan hard cover dan tebal 512 halaman - kamus ini belum pernah direvisi dan dimutakhirkan, baik dari segi penambahan kosakata baru (mufradāt jadìdah) maupun dari segi kontekstualisasi makna kata di dalamnya berikut penambahan diksi terjemahannya. Oleh karena itu, kritik leksikografis (naqd shinā'at al-mu'jam) terhadap kamus ini tidak hanya menarik, tetapi juga sangat signifikan (penting) dalam rangka menghadirkan karya leksikografis yang lebih aktual dan kontekstual, sesuai dengan perkembangan zaman dan kebutuhan masyarakat pengguna kamus.

Sementara itu, menurut penelitian an-Nasywān (2007: 516) dalam Jurnal Jami'ah Umm alQurā li 'Ulüm as-Syarī'ah wa al-Lughah al-'Arabiyyah wa Ādābihā, kompetensi penggunaan kamus (isti'māl al-qāmūs/al-mu'jam), terutama bagi peserta didik non-Arab, sangat diperlukan dalam proses pembelajaran bahasa Arab. Motivasi guru dan kecenderungan positif peserta didik dalam penggunaan kamus menunjukkan pengaruh signifikan terhadap kompetensi mereka dalam menggunakan sejumlah strategi penggunaan kamus, sehingga mereka memiliki kemandirian belajar, terutama dalam penguasaan kosakata dan komponen kebahasaan lainnya dari kamus yang digunakan.

\section{Metode Penelitian}

Berdasarkan pemikiran dan penelusuran penelitian terdahulu, studi ini berupaya mengkritisi dan memposisikan KMY dalam peta leksikografi Arab di Indonesia. Studi ini menjawab dua masalah utama. Pertama, "Apa kritik leksikografis yang relevan dialamatkan kepada kamus ini agar para pengguna kamus tidak keliru dalam memedomani arti dan diksi yang diberikan di dalamnya dalam penerjemahan entri berikut derivasinya?" Kedua, bagaimana memposisikan kamus ini dalam perkembangan peta leksikografi kamus Arab-Indonesia di tanah air?”

Berbasis studi literatur (kepustakaan) dengan pendekatan linguistik teks ("ilm al-lughah annașş $\bar{\imath}$ ) dan data yang bersumber dari konten KMY dimaknai dengan analisis isi (tahliil al-muhtawā), studi ini menghadirkan evaluasi dan kritik leksikografis yang krusial terhadap sistematika dan konten kamus tersebut. Data-data entri, ilustrasi, gambar berikut terjemahan dalam KMY dikategorikan sebagai teks bahasa (linguistic text) yang tertulis sekaligus sebagai unit semantik (wahdah dalāliyyah) yang berdimensi bentuk dan makna (form and meaning). Teks dalam KMY juga dipahami sebagai proses, produk, dan peristiwa komunikasi yang pemaknaannya sangat dipengaruhi konteks. Karena itu, kritik leksikografis terhadap KMY didasarkan pada tujuh kriteria linguistik teks, yaitu: kohesi, koherensi, intensionalitas, akseptabilitas, informativitas, situasionalitas, dan intertekstualitas (al-Fiqī, Jilid I, 2000: 29-34). Analisis isi teks KMY lebih bersifat kualitatif menurut Mayring (1988) dengan proses analisis yang terdiri dari sembilan tahap, yaitu: penentuan materi (evaluasi dan kritik KMY), analisis situasi tempat asal teks (tempat studi penulis kamus, Mesir dan Indonesia), pengarakteran materi, penentuan arah analisis, deferensiasi pertanyaan yang harus dijawab (sesuai dengan rumusan masalah tersebut), penyeleksian teknik-teknik analisis (ringkasan, eksplikasi, penataan), pendefinisian unit analisis, analisis materi teks, dan interpretasi (Titscher, et.al, 2009:108-108)

Selain itu, studi ini juga menjelaskan posisi kamus tersebut dalam peta perkembangan leksikografi Arab-Indonesia di Indonesia. Pemetaan posisi leksikografis KMY didasarkan pada delapan kategori kamus, baik oleh Ya'qūb maupun al-Qāsimī (al-Qāsimī, 1991:3-15). Studi kritik leksikografis ini diharapkan dapat memberikan evaluasi sekaligus apresiasi terhadap karya leksikografis lainnya, di samping menjadi bahan referensi dalam pengembangan kamus ArabIndonesia dan sebaliknya di masa mendatang, terutama dalam konteks pengembangan pembelajaran bahasa Arab di dunia Islam dan di Indonesia.

\section{Kamus sebagai Produk Leksikografi}

Sistem bahasa pada umumnya dikelompokkan menjadi empat subsistem, yaitu: sistem fonologi (an-nizhām as-shawtī), sistem morfologi (an-nizhām al-sharfî), sistem sintaksis (an- 


\section{Arabi : Journal of Arabic Studies}

nizhām al-nahwi), dan sistem semantik (an-nizhām al-dalāî́). Keempatnya memang merupakan ruang lingkup kajian linguistik (Qaddūr, 1999:257-260; Qaddūr, 2001:5-6). Sementara itu, Tammām Hassān (1998:3-6) menambahkan satu subsistem lagi, yaitu sistem leksikon (an-nizhām al-mu'jamî). Sedangkan Abdul Chaer (2007: 176) merangkum subsistem itu hanya menjadi tiga saja, yaitu: subsistem fonologi, subsistem gramatika, dan subsistem leksikon. Jadi, leksikon yang berkaitan dengan kosakata dan perbendaharaan kata itu merupakan bidang kajian linguistik yang dapat berdiri sendiri, dan telah melahirkan ilmu: leksikologi dan leksikografi.

Menurut Abdul Chaer (2007:176-177), hubungan antara leksikografi dan leksikologi sangat dekat, sehingga batas antara keduanya sulit ditentukan. Ilmu tentang leksikon disebut leksikologi (pakarnya disebut leksikolog), sedangkan penulisan mengenai leksikologi disebut leksikografi (pakarnya disebut leksikograf). Produk yang dihasilkan dari kerja leksikografi adalah kamus atau mu'jam. Menurut Ahmad Mukhtar Umar (1998:20-21), leksikologi memusatkan perhatian kepada studi kosakata, struktur dan maknanya; sedangkan leksikografi (fann șinā'at al-mu'jam) memfokuskan pada penyusunan kamus, teori dan metode yang menjadi dasar penyusunannya. Sementara itu, Ali Mahmud as-Sarrāf (2013:16) menjelaskan bahwa leksikologi dan leksikografi mempunyai obyek material studi yang sama, yaitu leksikon, namun berbeda obyek formalnya. Leksikologi berorientasi kepada studi leksikon dari segi teori keilmuannya, sedangkan leksikografi menitikberatkan kepada studi leksikon dari segi seni atau profesi penyusunnya. Dengan kata lain, leksikologi merupakan ilmu yang menjadi dasar atau pijakan dalam melakukan kerja leksikografi (penyusunan kamus), sehingga kamus yang dihasilkan sesuai dengan standar, sistem, dan metode tertentu dalam leksikologi.

Kamus bahasa, termasuk kamus dwibahasa Arab-Indonesia dan sebaliknya, merupakan "gudang" perbendaharaan kata dalam studi bahasa (Abdullah, 2012:105), sebab belajar bahasa asing bagi pembelajaran yang bukan penutur bahasa itu hampir mustahil bisa dilakukan dengan baik tanpa menggunakan kamus. Namun, keberadaan kamus bahasa Arab tampaknya belum dioptimalkan fungsinya dalam pembelajaran dan kajian bahasa Arab. Ada beberapa faktor yang menjadi penyebabnya. Salah satunya, berdasarkan pengamatan penulis di Jurusan Pendidikan Bahasa Arab (PBA) FITK UIN Syarif Hidayatullah Jakarta, adalah kemalasan dan rendahnya kesadaran guru/dosen dan siswa/mahasiswa dalam mendayagunakan kamus. Rendahnya kesadaran ini, antara lain, disebabkan oleh ketiadaan kamus yang memadai (memuaskan) atau tidak praktisnya kamus yang dipergunakan. Hal ini barangkali karena ukuran kamus terlalu tebal dan berat seperti kamus al-Munjid fi al-Lughah wa al-A'läm atau al-Munawwir. Dewasa ini, para mahasiswa cenderung menggunakan kamus digital yang aplikasinya dapat diunduh dan disimpan di ponsel (telepon seluler) berbasis android.

Secara etimologi, kamus (قاموس) berarti laut atau lautan yang luas (البحر المحيط). Kamus sinonim dengan muijam yang dalam bahasa Inggris disebut dengan dictionary dan dalam bahasa Jerman disebut Wörterbuch. Kata "mu'jam" itu sendiri pada awalnya berarti "tidak jelas, tidak fasih, atau asing." (An̄̄s et.al, 1972: 586). Selain itu, dalam perspektif lain, kamus juga mengandung arti: menjelaskan sesuatu (kata, istilah, ungkapan, frasa) yang masih kabur (belum jelas) dan asing. Kata "mu'jam"itu sendiri mempunyai dua arti yang saling berlawanan, yaitu: (1) tersembunyi dan samar (belum jelas); dan (2) menjelaskan dan menerangkan (ar-Rājih̄ī, 2002:139). Oleh karena itu, orang asing dalam bahasa Arab disebut ajam (Ya'qūb: 1981:13). Dengan demikian, eksistensi kamus berfungsi sebagai penjelas, penafsir, penerjemah arti, dan pemberi padanan kata dan makna terhadap kosakata, istilah, ungkapan atau frasa yang masih asing atau belum jelas sehingga menjadi lebih jelas dan dimengerti oleh penggunanya (Abdul Wahab, 2008:271). Kamus Arab-Indonesia bagi pembelajar bahasa Arab, tentu saja, sangat membantu proses pembelajaran keterampilan berbahasa Arab, karena dapat menjadi referensi dalam pencarian arti kosakata baru atau penggunaan kosakata dan istilah baru dalam aktivitas berbahasa Arab.

Menurut Ahmad al-'Āyid, et.al. (Tim Penyusun dari Pakar bahasa Arab ISESCO) (2003:823), kamus atau mu'jam (jamaknya ma'ājim) adalah buku yang memuat kosakata-kosakata

Vol. 2 No. 1 | 22-36

Copyright (C) 2017 | ARABI | p-ISSN 2548-6616 | e-ISSN 2548-6624 
bahasa yang disusun dengan sistematika tertentu, dan memuat penjelasan terhadap kosakata itu atau menyebutkan padanannya dalam bahasa lain. Kamus merupakan karya kebahasaan yang memuat sejumlah kosakata dalam suatu bahasa yang disertai dengan penjelasan derivasinya dan penafsiran maknanya, disusun menurut aturan tertentu dan dengan sistematika tertentu pula. Kamus bahasa, paling tidak, mengandung sejumlah entri (madkhal), kosakata berikut derivasi dan perubahan-perubahannya, yang kemudian diikuti dengan penjelasan arti, makna, sinonim ataupun antonimnya, bahkan contoh pengejaan atau pelafalan dan penggunaannya (Ya'qūb, 1981:9). Singkatnya, kamus merupakan buku mengenai kosakata suatu bahasa berikut arti atau padanan katanya yang disusun dengan aturan tertentu dan urutan huruf alfabetis tertentu (ad-Dāyah, 1999:11). Jadi, kamus merupakan referensi yang berisi daftar kata, frasa, ungkapan, berikut penjelasan makna dan penggunaannya yang disusun menurut sistem dan sistematika tertentu, baik penjelasan itu dalam bahasa yang sama (monolingual, unhādiyyah al-lughah), seperti al-Mu'jam alWasith maupun dalam dwibahasa atau lebih seperti KMY.

Sejalan dengan arti mu'jam itu sendiri, dapat dipahami bahwa tujuan utama penyusunan kamus adalah untuk memberi penjelasan dan pemaknaan mengenai suatu kata atau istilah yang masih belum jelas. Sesuai dengan arti kamus -diserap dan digunakan bangsa Arab berasal dari bahasa Yunani kuno, okeanos, yang berarti lautan (Abdul Chaer, 2007:179) - dapat dipahami bahwa kamus disusun tidak lain adalah agar para pembacanya dapat menyelami "lautan makna" suatu kata secara lebih jelas, termasuk sinonim, antonim dan derivasinya (isytiqāq). Dengan menyelami "lautan makna" yang ada dalam sebuah kamus, niscaya pembaca atau penggunanya akan memperoleh penjelasan, pengetahuan kebahasaan dan pemahaman yang lebih baik dan mendalam. Dengan membuka kamus, misalnya saja Mu'jam al-Lughah al-'Arabiyyah alMu'āshirah: 'Arabi-InkTiji karya Hans Wehr (1980), pembaca dapat mengetahui cara membaca setiap kosakata yang ada, berikut aneka diksi makna dan penggunaannya dalam bidang keilmuan tertentu.

Sejarah ilmu bahasa Arab dimulai dan diinspirasi oleh turunnya al-Qur'an. Studi tentang perkamusan Arab pada awalnya dimaksudkan untuk "melayani" kepentingan memahami ajaran Islam, khususnya untuk tujuan memahami al-Qur'an, sebagai sumber utama ajaran Islam. Dengan kata lain, al-Qur'an merupakan poros (mihwar) dan dasar studi bahasa Arab secara keseluruhan (Abd at-Tawwāb, 1987:229). Hal ini berarti bahwa penyusunan kamus Arab pada waktu itu, antara lain, dimaksudkan sebagai sarana untuk memfasilitasi siapapun dalam memahami bahasa alQur'an. Dengan kata lain, motivasi awal penyusunan kamus Arab (Kamus Arab-Arab) pada masa itu lebih bersifat religius, meskipun cara kerja -yang ditempuh oleh al-Khalīl ibn Ahmad alFarāhīdī (100-170 H) (al-Thanthāwī, 2002: 32; 'Akkāwì, 1993:119-225; dan Hijāzì, 1993:10-11) — sangat akademik dan ilmiah pada masanya, karena dia mendasarkan kerja leksikografinya berdasarkan grounded research dan dengan sistematika fonologis (urutan bunyi sesuai dengan makhraj, titik artikulasi), bukan urutan alfabetis.

Benih dan cikal bakal penyusunan kamus Arab itu, menurut at-Tawwāb, berasal dari metode tafsir Ibn 'Abbās. Ketika mendapati kata-kata yang dianggap sulit dalam al-Qur'an, Ibn 'Abbās mencari penjelasannya melalui syair Jāhilī, seperti ketika ia menafsirkan kata "al-wasỉlah" dengan "al-hājah" pada ayat "wa ibtaghū ilaih al-wasīlah" (QS. al-Māidah [5]:35). Jadi, syairsyair Jāhiliyah pada waktu itu dijadikan sebagai referensi dalam pemaknaan dalam memahami padanan kata atau ungkapan dalam al-Qur'an. Oleh karena itu, muncullah sebuah ungkapan yang sangat terkenal di kalangan bangsa Arab bahwa: "al-Syi'r Dïwān al- 'Arab" (Puisi itu merupakan antologi referensi bagi bangsa Arab) (Ibrāhīm, 2001: 145-146). Dengan demikian, salah satu sumber yang menjadi referensi dalam mengartikan dan menafsirkan kata-kata yang musykil dalam al-Qur' an adalah syair Jāhili. 


\section{Arabi : Journal of Arabic Studies}

\section{Perkembangan Leksikografi Arab}

Leksikografi kamus Arab secara akademik, dalam bentuknya sebagai karya linguistik yang komprehensif, sesungguhnya mulai muncul pada abad kedua hijriah. Pelopor leksikografi Arab adalah al-Khalīl $(100-170 \mathrm{H})$, seorang mahaguru nahwu dan linguistik Arab sekaligus pencetus dan perumus ilm al-'Arüdh. Kitāb al-'Ain, nama kamus Arab pertama yang disusunnya, merupakan karya yang lahir dari ijtihäd lughawi (ijtihad linguistik) yang luar biasa untuk ukuran zamannya, karena sistematika penyusunannya sangat saintifik, berdasarkan makhärij al-h̆hurüf dari huruf /ain/artikulasi huruf paling belakang/jauh dari bibir, yaitu makhraj halq $\bar{i}$ pada kerongkongan manusia - hingga $/ y \bar{a} /$, yang berartikulasi pada dua bibir (syafawi, bilabial). Selain itu, dalam menyusun sistematika entri kamusnya, al-Khalīl menggunakan metode "pembalikan konstruksi" bentuk kata (taqlib al-abniyah), sebagai media untuk membatasi lafaż bahasa secara matematis. (Qāsim, 1987:111)

Kodifikasi dan sistematisasi kamus Arab, paling tidak, mengalami tiga periode penting. Pertama, periode pembukuan (pencatatan) kata-kata tanpa sistematika tertentu dan pada umumnya tanpa ada penjelasan kata. Pada periode ini, tepatnya pada akhir abad pertama hijriah, dijumpai beberapa buku mengenai risālah al-Qur'an, seperti Gharīb al-Qur'ān karya Abī Sa'īe al-Bakrī (w. $141 \mathrm{H}$ ) dan Kitāb al-Nawādir karya beberapa orang seperti Abū 'Amr ibn al-'Alā' (w. $157 \mathrm{H}$ ), Yūnus ibn Habīb (w. 182 H), dan al-Kisā'̄ì (w. 198).(ad-Dāyah, 1999:13). Dalam periode ini, observasi lapangan dan penggunaan bahasa Arab dengan membuat "catatan lapangan" (field notes) seperti grounded research dilakukan sebagai upaya inputing perbendaharaan bahasa.

Kedua, periode penyusunan kosakata secara sistematis dalam buku kecil (saku), mengenai tema tertentu dan disistematisasikan berdasarkan huruf tertentu pula. Di antara risālah (traktat, karya) yang disusun pada periode ini adalah Kitāb al-Mathar wa Kitāb al-Laba' wa al-Laban karya Abū Zaid al-Anshārī dan Kitāb al-Khail, Kitāb al-Syitā', Kitāb Khalq al-Insān wa Kitāb al-Nakhl wa al-Karam, wa Kitāb al-Nabăt wa al-Syajar karya al-Ashmū'i (122-216 H.). Periode ini berlangsung pada awal dan pertengahan abad kedua hijriyah. Periode ini juga ditandai munculnya berbagai karya ensiklopedia mengenai kamus antonim, Kitāb al-Adhdād karya al-Ashmū'i, Ibn alSikkīt (802-858 M), maupun Abū at-Thayyib (w. $351 \mathrm{H})$. Kecenderungan lain dalam penyusunan kamus pada periode ini adalah adanya pembedaan, misalnya, antara fi'l dan ism, antara kata yang dibaca panjang dan pendek. Kamus mengenai hal ini, contohnya antara lain, adalah Kitāb alMaqshür wa al-Mamdūd karya Abū Zakariya al-Farrā (144-207 H).(ad-Dāyah, 1999:15-17)

Ketiga, kodifikasi kamus atau ensiklopedi secara komprehensif. Dalam hal ini, kamus komprehensif pertama di dunia Islam adalah karya al-Khalīl tersebut. Mulai periode ini, banyak ulama yang kemudian mengikuti sistem penyusunan kamus versi al-Khalīl, seperti al-Bāri' karya Abū 'Alī al-Qālī (288-356 H), meskipun ia sedikit melakukan perubahan pada urutan huruf dalam kamusnya (ad-Dāyah, 1999: 21-25). Jika Kitāb al-Ain sistematika (urutan) hurufnya dimulai sebagai berikut:

\section{اع/ح/ه/خاغ/ق/ك/ج/ش/ض/ص/س/ز/ط/د/ت/ظ/ذ///ال/ن/ف/ب/م/و/اي|}

maka al-Bāri' disusun dengan urutan huruf sebagai berikut:

\section{|هـ/ح/ع/خاغ/ق/ك/ض/ج/ش/ال/ران/ط/د/ت/ص/ز/س/ظ/ذ/ث/ف/ب/م/و/اي|}

Dalam perkembangan berikutnya, penyusunan kamus Arab mulai disusun berdasarkan abjad atau alfabet Arab yang dikenal dewasa ini, seperti yang digunakan oleh al-Munjid, atau al-Mu'jam al-Wasith dan al-Mu'jam al-'Arabī al-Asāsī. Kedua kamus terakhir diterbitkan melalui kerja leksikografi kolektif, baik oleh Majma' al-Lughah al-'Arabiyyah Kairo maupun tim pakar bahasa Arab ISESCO (Islamic Education, Sciences, and Culture Organisation) yang berpusat di Rabath Marokko. 
Penyusunan kamus kini telah menjadi sebuah ilmu yang berdiri sendiri, yang disebut dengan 'ilm al-mujamāt/al-ma'ājim (Leksikologi). Hal ini dikarenakan kamus tidak lagi terbatas untuk kepentingan agama, budaya dan bangsa tertentu, melainkan juga dikembangkan untuk mengabdi kepada kepentingan akademik-ilmiah. Karena itu, kamus-kamus bahasa Arab belakangan ini sudah mengalami spesialisasi yang luar biasa pesat (Hijāzī, 1993:83). Lebih dari itu, dalam linguistik terapan muncul pula ilmu baru yang berkaitan dengan peristilahan yang disebut dengan 'ilm al-Musțalah, sebuah ilmu yang mengkaji kriteria dan standarisasi istilah-istilah yang digunakan dalam bidang-bidang keilmuan tertentu sesuai dengan disiplin ilmu masing-masing (Hijāzī, 1993:16). Spesialisasi atau tematisasi kamus mulai berkembang sejak tahun 1970-an, setelah beberapa negara di Timur Tengah mulai banyak bergumul dengan -atau terpengaruh oleh dinamika leksikologi - Barat, utamanya dalam rangka studi dan eksplorasi minyak, sehingga proses transformasi teknologi mengalami akselerasi dan dengan sendirinya usaha untuk melakukan "Arabisasi" istilah-istilah teknologi pun berkembang dinamis. Spesialisasi dan tematisasi itu, antara lain, terlihat pada terbitnya beberapa kamus sebagai berikut:

\begin{tabular}{|c|c|c|c|}
\hline Bidang/Tema & Judul Kamus & Penulis & Terbitan \\
\hline Pendidikan & معجم المصطلحات التربوية & $\begin{array}{l}\text { Ramzi Kamel } \\
\text { Hannallah dan } \\
\text { Mechael Takta } \\
\text { Guirguis }\end{array}$ & $\begin{array}{l}\text { Beirut: } \\
\text { Maktabah } \\
\text { Lubnān, } 1998\end{array}$ \\
\hline Psikologi & معجم التربوية المصطلحات النفسية & $\begin{array}{l}\text { Muhammad } \\
\text { Mushthafā Zaidān }\end{array}$ & $\begin{array}{l}\text { Beirut: Dār al- } \\
\text { Syurūq, } 1984\end{array}$ \\
\hline Sosial & الاجتماعية معطلحات العلوم & $\begin{array}{l}\text { Ahmad Zakī } \\
\text { Badawi }\end{array}$ & $\begin{array}{l}\text { Beirut: } \\
\text { Maktabah } \\
\text { Lubnān, } 1982 \\
\end{array}$ \\
\hline Politik & معجم العبارات السياسية الحديثة & Majdī Wahbah & $\begin{array}{l}\text { Beirut: } \\
\text { Maktabah } \\
\text { Lubnān, } 1978\end{array}$ \\
\hline Hukum & المعجم القانوني & $\begin{array}{l}\text { Hârits Sulaimān } \\
\text { al-Fāruq̄i }\end{array}$ & $\begin{array}{l}\text { Beirut: } \\
\text { Maktabah } \\
\text { Lubnān, } 1991 \\
\end{array}$ \\
\hline Ekonomi & و معجم و مصطل وإدة الأموات الاقتصاد & Nabīh Ghattās & $\begin{array}{l}\text { Beirut: } \\
\text { Maktabah } \\
\text { Lubnān, } 1985\end{array}$ \\
\hline Kedokteran & قاموس "حتي" الطبي الجديد & $\begin{array}{l}\text { Yûsuf Hittī dan } \\
\text { Ahmad Syafî̀ al- } \\
\text { Khathîb }\end{array}$ & $\begin{array}{l}\text { Beirut: } \\
\text { Maktabah } \\
\text { Lubnān, } 1993\end{array}$ \\
\hline Matematika & معجم الرياضيات & Tim Penyusun & $\begin{array}{l}\text { Beirut: } \\
\text { Maktabah } \\
\text { Lubnān, } 1987\end{array}$ \\
\hline Informatika & قاموس مصطلحات المعلو ماتية & E.W. Haddād & $\begin{array}{l}\text { Beirut: } \\
\text { Maktabah } \\
\text { Lubnān, } 1988\end{array}$ \\
\hline Pertanian & العلوم الزراعية الثهابي في مصطلحات & $\begin{array}{l}\text { Ahmad Syafìq al- } \\
\text { Khatīb }\end{array}$ & $\begin{array}{l}\text { Beirut: } \\
\text { Maktabah } \\
\text { Lubnān, } 1987 \\
\end{array}$ \\
\hline $\begin{array}{c}\text { Sains, } \\
\text { Teknologi \& } \\
\text { Seni } \\
\end{array}$ & و الفنية و التقنية المصطلحات العلمية & $\begin{array}{l}\text { Ahmad Syafĩq al- } \\
\text { Khatīb }\end{array}$ & $\begin{array}{l}\text { Beirut: } \\
\text { Maktabah } \\
\text { Lubnān, } 1991 \\
\end{array}$ \\
\hline Manajemen & معجم الإدارة & Nabīh Ghattās, & Beirut: \\
\hline
\end{tabular}


Arabi : Journal of Arabic Studies

\begin{tabular}{|c|c|c|c|}
\hline & & et.al & $\begin{array}{l}\text { Maktabah } \\
\text { Lubnān, } 1984\end{array}$ \\
\hline Perdagangan & و معجم التجارية المصطلحات الاقتصادية & $\begin{array}{l}\text { Majdī Wahbah \& } \\
\text { Kāmil al- } \\
\text { Muhandis }\end{array}$ & $\begin{array}{l}\text { Beirut: } \\
\text { Maktabah } \\
\text { Lubnān, } 1982\end{array}$ \\
\hline Filsafat & المعجم الفلسفي (مجلدان) & Jamīl Shalībā & $\begin{array}{l}\text { Beirut: Dār al- } \\
\text { Kitāb al- } \\
\text { Lubnānī, } 1982 .\end{array}$ \\
\hline Perminyakan & و معجم مالصناعة النفطية & $\begin{array}{l}\text { Ahmad Syafĩq al- } \\
\text { Khathîb }\end{array}$ & $\begin{array}{l}\text { Beirut: } \\
\text { Maktabah } \\
\text { Lubnān, } 1975\end{array}$ \\
\hline Diplomasi & معجم الدولية الدبلوماسية والثئون & $\begin{array}{l}\text { Sumūhī Fawqa al- } \\
\text { Adah }\end{array}$ & $\begin{array}{l}\text { Beirut: } \\
\text { Maktabah } \\
\text { Lubnān, } 1984\end{array}$ \\
\hline Militer & القاموس العسكري العربي & $\begin{array}{l}\text { Tim Penerjemah } \\
\text { dari bahasa Inggris } \\
\text { ke dalam bahasa } \\
\text { Arab }\end{array}$ & $\begin{array}{l}\text { London: } \\
\text { Routledge \& } \\
\text { Keagan Paul, } \\
1986\end{array}$ \\
\hline Komputer & و معجم الحصبات الإلكترونيةت المعلوماتية & D. Cusic & $\begin{array}{l}\text { Beirut: } \\
\text { Maktabah } \\
\text { Lubnān, } 1988\end{array}$ \\
\hline Linguistik & ـ معجم - معلم علم اللغة النظري التطبيقي & $\begin{array}{l}\text { Muhammad 'Alī } \\
\text { al-Khūlī }\end{array}$ & $\begin{array}{l}\text { Beirut: } \\
\text { Maktabah } \\
\text { Lubnān, } 1982 \text { \& } \\
1986\end{array}$ \\
\hline $\begin{array}{l}\text { Bahasa dan } \\
\text { Sastra }\end{array}$ & معجة اللغة الأدبط المعات العربية في & $\begin{array}{l}\text { Majdi Wahbah \& } \\
\text { Kamil al- } \\
\text { Muhandis }\end{array}$ & $\begin{array}{l}\text { Beirut: } \\
\text { Maktabah } \\
\text { Lubnān, } 1984\end{array}$ \\
\hline $\begin{array}{l}\text { Teknik- } \\
\text { Mekanik }\end{array}$ & معجم الميكانيكية مصطلحات الهندسة & $\begin{array}{l}\text { Tim Lembaga } \\
\text { Bahasa Arab Kairo }\end{array}$ & $\begin{array}{l}\text { Kairo: Lembaga } \\
\text { Bahasa Arab, } \\
1998\end{array}$ \\
\hline Geografi & معجم المصطلحات الجغر افية & $\begin{array}{l}\text { Pierre George, } \\
\text { diarabkan oleh } \\
\text { Hamd at-Thufailī }\end{array}$ & $\begin{array}{l}\text { Beirut: al- } \\
\text { Muassasah al- } \\
\text { Jāmi'iyyah, } \\
2002 \text {. }\end{array}$ \\
\hline $\begin{array}{l}\text { Dokumen dan } \\
\text { kearsipan }\end{array}$ & والأرشيف مصطلحات الوثائق & Salwā Alī Mīlād & $\begin{array}{l}\text { Kairo: Dār aś- } \\
\text { Śaqāfah, } 1982 .\end{array}$ \\
\hline Idiom & قالاصوسلاحية أطلس للتعبيرات & Fatimah Syaraf & $\begin{array}{l}\text { Kairo: } \\
\text { Maktabah Ibn } \\
\text { Sina, } 2005\end{array}$ \\
\hline $\begin{array}{l}\text { Evaluasi } \\
\text { Bahasa }\end{array}$ & معجم تقويم اللغة وتخليصها من & Hallā Ammūn & $\begin{array}{l}\text { Beirut: Dār al- } \\
\text { Qalam, } 2002\end{array}$ \\
\hline
\end{tabular}

Penyebutan 25 kamus atau mu'jam tersebut hanyalah sekadar untuk menunjukkan kepada masyarakat akademik bahasa Arab bahwa dunia leksikografi (dalam bahasa Arab) sesungguhnya merupakan dunia keilmuan yang cukup menarik untuk dikaji dan dikembangkan. Hampir semua bidang ilmu sudah dibuat kamusnya, termasuk kamus bidang ilmu bahasa Arab, seperti: nahwu, sharaf dan balaghah. Selain itu, penyebutan tersebut juga menjadi bahan komparasi dan evaluasi akademik-ilmiah bahwa perkembangan kamus bahasa Arab di Indonesia, relatif masih tertinggal 
jauh dibandingkan dengan di negara-negara Timur Tengah. Dalam kontek ini, sejumlah penerbit di Beirut Lebanon berperan penting dalam publikasinya.

Selain itu, penting pula ditegaskan bahwa jumlah kamus dalam bahasa Arab mungkin merupakan kamus yang paling banyak disusun di dunia saat ini. Dari bibliografi perkamusan Arab diketahui paling tidak ada sekitar seribu kamus Arab. Jumlah kamus dimaksud berupa kamus monolingual, bilingual, trilingual, kamus umum, kamus istilah, ensiklopedi dalam berbagai bidang ilmu, dan daftar istilah. Selain itu, termasuk dalam karya leksikografis adalah indeks Al-Qur'an maupun Indeks Hadis. Karya-karya leksikografis Arab biasanya berbentuk: (1) daftar istilah yang tersebar dan dipublikasikan pada berbagai jurnal berkala atau majalah misalnya, jurnal al-Lisān alArab̄ yang diterbitkan oleh Jāmi'at ad-Duwal-Arabì. Selain itu, dapat diketahui pula dari Majallah Kulliyat al-Adab, Jāmi'at al-Imām Muhammad Ibn Saūd al-Islāmiyyah Riyadh dan

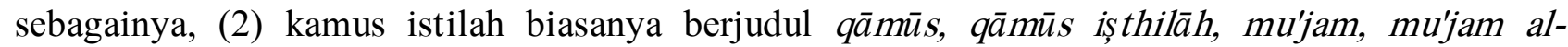

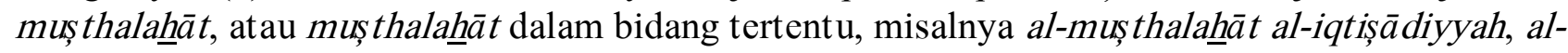
mușthalahāt al-tarbawiyyah, al- mussthalahāt al-nahwiyyah, dan lain sebagainya. Karya-karya leksikografis Arab meliputi ensiklopedi, kamus ensiklopedis, kamus, mu'jam, mu'jamulmușthalahăât, dan daftar istilah (Shafwān, 2012; dan Qāsim, 1987). Dengan demikian, kamus bukan sekadar kumpulan kosakata. Menurut Tammām Hassān (2007:346-347), kamus merupakan sebuah sistem (nizam al-mu'jam) terintegrasi dengan sistem bahasa lainnya (fonologi, morfologi, sintaksis, semantik) dalam memproduksi teks kebahasaan melalui narasi entri kata berikut derivasinya dengan tata cara membacanya, aneka diksi, sinonim, antonim, berikut contoh dan konteks penggunaannya.

\section{KMY dalam Peta Leksikografi Arab}

Jika kamus pertama karya Mahmud Yunus, kamus al-shāhibì, masih ada dan terbit, tampaknya dapat dikatakan bahwa Mahmud Yunus adalah pelopor atau perintis leksikografi Arab di Indonesia. Sayangnya, kamus ini tidak lagi dapat ditemukan (mungkin keluarga beliau menyimpan koleksinya). Penilaian penulis bahwa Mahmud Yunus layak disebut sebagai perintis perkamusan bahasa Arab karena kamus Arab-Melayu yang terbit setelah al-Śāhibì adalah kamus al-Marbawi yang disusun oleh Muhammad Idris al-Marbawi pada tahun 1931, dan kamus ini dipandang sebagai kamus pertama (Arab-Melayu) di dunia Melayu (Abdullah, 2013:107)

Sejarah kamus Arab-Indonesia telah diawali oleh kamus Arab-Melayu. Pada awal pertumbuhan kamus Arab Melayu, setidaknya ada tiga kamus yang banyak dipakai oleh masyarakat Indonesia antara lain: kamus al-Inārah al-Tahżbiyyah, kamus Idris al- Marbawi dan kamus az-Zahabì. Kamus trilingual (Arab-Inggris-Indonesia) pertama kali adalah kamus karya Omar Bakri dan Abdullah bin Nuh yang dipublikasikan pada tahun 1953. Hingga tahun 1970-an, kamus bahasa Arab yang terbit di Indonesia pada umumnya adalah kamus bilingual.

Setelah sekian lama tidak terdapat publikasi kamus Arab, terbitlah kamus al-Munawwir: Arabi-Indunisi karya Ahmad Warson Munawwir pada tahun 1984. Di Era 1980-an ini praktis kamus ini menjadi primadona, karena tidak ada yang menyainginya, baik dari segi kebaruan maupun kelengkapannya. Kamus ini sejatinya merupakan "terjemahan" dari kamus al-Munjid. Pada era ini terbit pula kamus Indonesia-Arab karya al-Kalali yang juga nyaris tidak mendapat "pesaing". Selain itu, pada tahun 1980, Majmù 'àt 'Aşriyyah fi al-Lughah al-'Arabiyyah karya Hasan Ahmad Baharun juga dipublikasikan, sebagai bentuk pengenalan kosakata dan istilah modern yang tidak tercakup dalam kamus sebelumnya. Buku antologi kebahasaaraban ini memuat kosakata harian, kosakata kontemporer (tahun 1980an), sinonim dan antonim, contoh korespondensi, dan beberapa tema khutbah (Baharun, 1980:7). Kemudian di era 1990-an muncullah kamus "al- 'Ashrī dan al-Bisyri" yang lebih mutakhir lagi.

Pada tahun 2000-an upaya kontekstualisasi kamus mulai dilakukan. Adalah Basuni Imamuddin, dosen UI, dan istrinya, Nashiroh Ishaq, yang mempelopori penyusunan dan penerbitan kamus kontekstual Arab-Indonesia pada tahun 2001, dan dua tahun kemudian Basuni juga 


\section{Arabi : Journal of Arabic Studies}

menerbitkan kamus Idiom Arab-Indonesia. Di era 2000-an terbit pula Kamus Jamak Taksir ArabIndonesia dan Indonesia-Arab karya Syamsul Hadi, guru besar UGM, pada tahun 2002. Dan di akhir dekade 2000-an, terbit pula kamus “Abbas-Athiyah": Indonesia Arab Kontemporer (2009) karya Ainul Heri Abbas, dari Pesantren Mambaus Sholihin Gresik. Terakhir, pada awal dekade 2010-an, Nur Mufid, dosen sastra Arab IAIN Sunan Ampel Surabaya, alumni Fakultas Adab IAIN Jakarta, menulis dan mempublikasikan kamus yang diklaim sebagai kamus modern, berjudul “Kamus Modern al-Mufid Indonesia-Arab”.

Dari uraian dinamika perkembangan leksikografi Arab di Indonesia tersebut dapat ditegaskan bahwa kamus Arab yang banyak dibuat di Indonesia pada umumnya kamus bilingual (dwibahasa), meskipun ada juga kamus trilingual. Kamus-kamus Arab-Indonesia atau sebaliknya belum berorientasi kepada kamus istilah atau kamus tematik. Kamus yang agak spesifik, seperti kamus Jamak Taksir, sudah mulai dibuat. Beberapa kamus tematik, seperti mu'jam an-Nūr li atTarbiyah wa al-Bahss al-'Ilmī karya Nuryani, dosen PBA IAIN Tulungagung, juga mulai muncul (Nuryani, 2015:1251). Sementara itu, kontekstualisasi leksikografi kamus Arab di era decade 2000an mulai dilakukan dan dimutakhirkan sesuai dengan tuntutan zaman dan perkembangan sains dan teknologi, seperti terlihat pada kamus kontekstual karya Basuni maupun kamus modern alMufid karya Nur Mufid. Dengan demikian, KMY termasuk kamus bilingual (Arab-Indonesia) yang relatif sangat populer dan banyak digunakan di kalangan pembelajar bahasa Arab di Indonesia.

\section{Profil Kamus Mahmud Yunus (KMY)}

Kontribusi intelektual Mahmud Yunus di bidang bahasa Arab cukup signifikan, baik terkait pembelajaran bahasa Arab maupun pengembangan karya perkamusan (leksikografi). Setidaknya Metodik Khusus Bahasa Arab dan Kamus Arabi-Indunisi karya Mahmud Yunus merupakan bukti perhatiannya terhadap pendidikan bahasa Arab. Karena itu, adalah wajar dan menarik apabila pemikiran pembaruan pendidikannya mendapat apresiasi, terutama di bidang perkamusan ArabIndonesia.

Secara sosial-intelektual, Mahmud Yunus termasuk salah satu mahasiswa Indonesia yang banyak dipengaruhi oleh lingkungan akademik (bahasa Arab) yang tepat, yaitu di Fakultas Dār al'Uhūm Universitas Kairo (Jāmi'ah al-Qāhirah). Universitas Cairo yang terletak di distrik Giza merupakan universitas modern yang didirikan pada masa pendudukan Inggris, tepatnya pada 21 Desember 1908. Berbeda dengan fakultas lainnya, Fakultas Dâr al- 'Ulûm, salah satu fakultas pada universitas ini, mempunyai reputasi yang baik di bidang studi bahasa Arab. Sejak semula, fakultas ini didesain untuk pusat studi bahasa Arab. Dari fakultas inilah banyak bermunculan pakar bahasa Arab (linguis, ahli nahwu, peneliti bahasa Arab) seperti: Thanthāwā Jauharī, Muhammad 'Athiyah al-Abrāsȳ̄ (1922), 'Alī al-Jārim (1908), Alī 'Abd al-Wāhid Wāfì (1925), 'Ābd al-'Âl Sâlim Makram (1950), 'Abd as-Şabūr Syāhīn (1956), Aḥmad 'Umar Mukhtār (1958), dan Tammām Hassān (w. Oktober 2011). Oleh karena itu, Muhammad 'Abduh (w. 1905) pernah menyatakan: "Seorang peneliti yang cermat jika ingin mengetahui di mana bahasa Arab itu mati dan di mana bahasa Arab itu hidup, maka ia akan mendapatinya mati di hampir setiap tempat; sementara bahasa Arab terus hidup di fakultas ini (Fakultas Dār al-'Ulūm).” (Sāmir Halabī, http://WWW.alhandasa.net/, 12 Juni 2012). Sementara, Fakultas Dār al-'Ulām merupakan fakultas yang melahirkan banyak pakar bahasa Arab. Yang menarik adalah bahwa ahli bahasa Arab yang membidani Jurusan Pendidikan Bahasa Arab, dan Bahasa dan Sastra Arab di UIN Jakarta adalah alumni Dār al-'Uhumm, yaitu: Mahmud Yunus dan Bustami Abdul Gani (1912-2001). Mahmud Yunus adalah alumni pertama Dār al-'Uhum dari Indonesia pada 1929. Sedangkan Bustami A. Gani menyelesaikan studinya pada Dār al-'Uhum pada 1939 (Armai Arief dan Muhbib Abdul Wahab, 2009: 41-73 dan 113-140). Jadi, Mahmud Yunus memang layak dianggap sebagai tokoh perintis pengembangan kajian bahasa Arab di Indonesia, setidaknya di bidang pembelajaran dan kamus bahasa Arab-Indonesia. 
KMY merupakan kamus Arab kedua, setelah kamus al-Marbaw, yang banyak beredar di Indonesia. Sebenarnya kamus ini merupakan "edisi revisi" dari kamus yang disusunnya ketika menjadi mahasiswa pada Fakultas Dār al-'Ulūm Universitas Kairo Mesir pada tahun 1929. Pada waktu Mahmud Yunus telah merintis penyusunan kamus “as-Śāhibī: Arab-Melayu”, dan telah mengalami beberapa kali cetak ulang (Mahmud Yunus, 1990). Dengan kata lain, Mahmud Yunus dapat dipandang sebagai perintis/pelopor leksikografi Arab-Indonesia di tanah air. Mahmud Yunus menyadari kebutuhan para pembelajar dan guru bahasa Arab di Indonesia yang memerlukan kamus sebagai media untuk mengakses makna bahasa dan memperkaya perbendaharaan bahasa Arab mereka. Sebagai mahasiswa pertama yang belajar di Kairo Mesir, Mahmud Yunus terpanggil untuk menyusun kamus guna membantu generasi muda Indonesia yang berminat mempelajari bahasa Arab.

Tebal KMY sebanyak 518 halaman (edisi terbaru, 2016, sebanyak 512 halaman) dengan format sedang, berukuran 13,5 x $19 \mathrm{~cm}$, berbobot 7,5 ons. Kamus ini terdiri dari kata pengantar penerbit, kata pengantar penulis, kamus bergambar yang, menurut pengakuan penulis, disadur dari kamus al-Munjid karya Louis Ma'lūf. Kamus bergambar ini memuat alat-alat sekolah, pakaian, perkakas dapur/makan, sayur-sayuran dan rempat, buah-buahan, alat-alat perhubungan/transportasi, alat-alat musik, senjata, manusia dan organ tubuhnya, alat-alat pertanian, rumah tangga, binatang/hewan, ikan, dan burung. Semua ilustrasi itu setebal 25 halaman. Harga terbaru kamus ini adalah Rp. 70.000,- (tujuh puluh ribu rupiah). Dari segi ukuran, KMY tergolong kamus sedang (menengah), tidak terlalu tebal dan tidak juga terlalu tipis, memadai untuk rujukan para pembelajar.

KMY disusun secara alfabetis, dimulai dari huruf alif hingga huruf $y \bar{a}$ '. Kamus ini dilengkapi dengan daftar pustaka; sebanyak 13 buku yang menjadi referensinya, disertai dengan daftar singkatan (Arab maupun Indonesia), peringatan dalam penggunaan kamus, dan cara pemakaian kamus ini, dengan menampilkan beberapa bentuk $\operatorname{taş} \bar{n} f$ (perubahan) kata berikut wazan (formula)nya. Ketika diminta untuk menulis ulang khat Arab kamus ini, setelah direvisi oleh Alm. Moh. Mansur. Moh. Matsna, dan Aziz Fakhrurrozi, penulis mendapati jumlah mufradāt (kosakata) dalam kamus berkisar 23.040 kosakata. Hal berarti bahwa KMY berisi jumlah kosakata yang mencukupi untuk membantu pembelajar dalam pengembangan empat keterampilan berbahasa (istimā', kalām, qirā'ah, kitābah). Akan tetapi, untuk penerjemahan teks Arab ke dalam bahasa Indonesia, terutama isu-isu kontemporer, KMY belum sepenuhnya dapat "memuaskan" penggunanya, karena beberapa entri, arti dan diksi yang ditawarkan tidak memadai.

Sistem penyusunan kamus ini mengikuti manhaj șarfi (metode morfologi) dengan mangacu aş1 al-isytiqā q atau al-jadzr (akar kata). Semua kata, derivasi, dan kalimat yang ditulis dalam kamus ini diberi syakal (cara membacanya). Sebagian entri kata diberi contoh berupa kalimat lengkap dan sebagian besar dilengkapi contoh berikut konteks penggunaannya. Beberapa kasus pengartian dalam kamus ini cenderung mengikuti nuansa bahasa Indonesia pada saat kamus ini pertama kali diterbitkan tahun 1972. Sejak pertama diterbitkan hingga sekarang, kamus ini belum pernah direvisi. Upaya revisi yang pernah dirintis oleh dosen PBA tersebut batal dipublikasikan karena ada perselisihan dengan ahli warisnya tentang royalti hak karya intelektual.

\section{Kritik terhadap KMY}

KMY dipastikan telah menjadi referensi yang turut berkontribusi dalam "menyarjanakan" dan "mendoktorkan" sekian banyak lulusan perguruan tinggi. Kontribusi kamus ini tergolong signifikan (besar) bagi proses pembelajaran bahasa Arab di Indonesia. Namun demikian, kamus ini tidak lepas dari kekurangan dan keterbatasan. Terlebih lagi, kamus ini tidak pernah mengalami pemutakhiran (updating) dan banyak kosakata baru yang tidak tercakup atau terhimpun dalam kamus ini. Misalnya saja kosakata yang terkait dengan teknologi informasi dan komunikasi seperti: عولمة، إنترنت، بريد إلكتروني، بث مباتشر، تعلّم إلكتروني، موقع الإنترنت، جوّال، حاسوب دفتري أو حاسوب 


\section{Arabi : Journal of Arabic Studies}

إرهابية، :dan sebagainya. Demikian pula kosakata terkait dengan sosial politik, seperti محمول، محمول dan sebagainya.

Berdasarkan pembacaan kamus dengan pendekatan linguistik teks, ada sejumlah kritik yang bisa dialamatkan kepada kamus Mahmud Yunus. Pertama, aspek şarfi (morfologi). Kamus ini, terutama pada bagian huruf Alif, terlihat belum konsisten. Banyak entri (madkhal) kata dalam bagian Alif yang campur aduk, tidak berdasarkan urutan awal kata. Misalnya saja, kata باح diletakkan di bagian huruf alif, bukan $b \bar{a}$ ' karena akar katanya adalah باح اتنق diletakkan pada وفق . Jadi, kamus ini belum sepenuhnya mengikuti metode şarfi berdasarkan jadzr secara konsisten dan akurat.

Kedua, aspek semantik. Dalam konteks ini, penulis melihat bahwa KMY memuat sejumlah padanan mufradāt Arab dalam bahasa Indonesia yang dari segi diksi (pilihan kata) kurang tepat. Tidak sedikit pengartian padanan kata dalam kamus ini menggunakan ungkapan: sejenis, sebangsa, nama sebuah.... dan sebagainya. Selain itu, ada pula mufradāt yang diberikan padanan yang tidak tepat dan tidak komprehensif, sesuai dengan cakupan makna yang dikandung oleh mufradàt itu. Berikut ini adalah beberapa contoh kasus semantikal dalam KMY.

\begin{tabular}{|c|c|c|}
\hline Arti versi penulis & Arti versi KMY & المفردات العربية \\
\hline+ administrasi, manajemen & Pejabat, kantor & إدارة \\
\hline $\begin{array}{l}\text { + etika; sastra (sebagai } \\
\text { tambahan) }\end{array}$ & Adab, tertib, sopan & آداب \\
\hline Lebih tepat: dilemma & Tempat sempit & مأزق \\
\hline + elegan (tambahan diksi) & Elok, indah, rapi & أناقة \\
\hline + kompetensi, keahlian & Patut, layak & أهلية \\
\hline + siaran (diksi kontemporer) & Bercerai berai, sangat kesusahan & البَتُ \\
\hline Cukup: selimut & $\begin{array}{l}\text { Kameli, kambeli, kain dari bulu } \\
\text { domba untuk selimut }\end{array}$ & بطانية \\
\hline $\begin{array}{l}\text { + mensurvey, survey دراسة, dalam konteks penelitian } \\
\text { (مسحية, }\end{array}$ & Menyapu, menghapus & 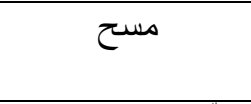 \\
\hline $\begin{array}{l}\text { + merekomendasikan; تزكية= } \\
\text { surat rekomendasi (untuk } \\
\text { keperluan studi atau yang lain). }\end{array}$ & Menyucikan, membayarkan zakat & زكّى يزكي تزكية \\
\hline Cukup: mineralogi (diksi baku) & $\begin{array}{l}\text { Ilmu mengeluarkan barang } \\
\text { tambang }\end{array}$ & علم المعادن \\
\hline Cukup: buah pear atau إجاصة & $\begin{array}{c}\text { Nama buah-buahan bentuknya } \\
\text { seperti buah pokat }\end{array}$ & كُكَّنَرَى \\
\hline + kanker (istilah medis) & $\begin{array}{l}\text { Ketam, kepiting, serangkak; suatu } \\
\text { buruj di langit; lari kencang }\end{array}$ & سَرَطَان \\
\hline + teologi (tambahan diksi) & Ilmu ketuhanan & علم الإلهيات \\
\hline
\end{tabular}

Dari beberapa kasus tersebut dapat disimpulkan bahwa sebagian terjemahan dan diksi arti yang diberikan KMY dalam memberi padanan kata dalam bahasa Indonesia cenderung merupakan hasil terjemahan secara leterlek dari kamus al-Munjid atau al-Wasith, tanpa dibarengi dengan upaya kontekstualisasi, pengecekan/perbandingan, dan pengayaan arti dari kamus-kamus lain, terutama kamus istilah atau kamus tematik sesuai dengan bidang ilmu. Hal ini barangkali dapat "dipahami" karena pada masa itu kamus pembanding, terutama kamus tematik sesuai dengan bidang keilmuan, relatif masih sedikit dan terbatas.

Ketiga, karena tidak pernah dimutakhirkan dan dikontekstualisasi, baik oleh penulisnya sendiri atau ahli warisnya, KMY cenderung statis (status quo), tidak ada penambahan entri, kosakata baru sesuai dengan perkembangan sains dan teknologi, serta tidak ada revisi atas sejumlah kesalahan, baik kesalahan pengartian padanan kata maupun kesalahan tulis/cetak. Contoh 
kata حَمْلة masih diartikan dengan serangan dan serbuan, padahal bisa juga diartikan dengan kampanye. Kata مُحام diartikan yang memelihara, yang membela, adpokat (seharusnya: advokat), padahal bisa juga ditambahkann dengan arti pengacara, pembela, penasehat hukum.

Keempat, KMY cukup banyak memuat kosakata Arab 'Amiyyah, terutama 'āmiyyah dialek Mesir. Hal ini boleh jadi akibat "kebiasaan berbahasa Arab" dialek Mesir yang dipraktikkannya selama studi di Mesir. Selain itu, barangkali pertimbangan praktis-pragmatis inilah yang membuat Mahmud Yunus mencantumkan kosakata 'āmiyyah yang sejatinya memang dibutuhkan oleh pelajar Indonesia ketika akan menempuh studi dan hidup di negara Timur Tengah, terutama Mesir. Berikut ini adalah beberapa kosakata 'ammiyyah yang dimuat dalam kamusnya, dan sebagai bukti kejujurannya, beliau mencantumkan kata 'āmmiyah setelah kosakata dan diletakkan dalam dua tanda kurun.

\begin{tabular}{|c|c|c|}
\hline Mufradat Fushha & Arti versi KMY & المفردات العامية \\
\hline \multirow[t]{2}{*}{ الحافلة } & Oto bus & أمنييوس \\
\hline & Barang antik & أنتيكة \\
\hline \multirow[t]{2}{*}{ السفينة } & Kapal api & بابور \\
\hline & Kepala, yang pertama & باشٍ \\
\hline \multirow[t]{4}{*}{ عَلْم، لو اواء } & Bendera & بنديرة \\
\hline & Periuk api, kembang api & توربيد \\
\hline & Basah kuyup & عُصنرة \\
\hline & Tukang api & عطشجي \\
\hline بيّاع جوّال،PKL & Penjual berjaja & عِ عِقاش \\
\hline
\end{tabular}

Kelima, karena tidak dimutakhirkan, direvisi dan dilengkapi, dengan sendirinya KMY tidak sepenuhnya lagi dapat memenuhi kebutuhan dan perkembangan mutakhir terkait berbagai kosakata yang muncul dalam 45 tahun terakhir (sejak kamus itu diterbitkan pada 1972). Oleh karena perkembangan kosakata bahasa Arab juga tidak luput dari pengaruh bahasa asing, terutama bahasa Inggris, maka dapat dipastikan bahwa beberapa kosakata berikut -yang dicermati dan dicatat penulis dari perkembangan kebahasaaraban kontemporer- entri dan diksinya tidak dapat dijumpai dalam KMY.

\begin{tabular}{|c|c|c|c|}
\hline Nasionalisasi & توطين & Reboisasi & تشجير \\
\hline Modernisasi & تحديث & Generalisasi & تعميم \\
\hline Standarisasi & تقييس/تقنين & Sterilisasi & تعقيم \\
\hline Aritmatisasi & تحسيب & Fungsionalisasi & توظيف \\
\hline Matematisasi & ترويض & Westernisasi & تغريب \\
\hline Islamisasi & أسلمة & Swastanisasi & أهلنة \\
\hline Klusterisasi & عنقدة & Rasionalisasi & عقلنة \\
\hline Lokalisasi & مَوْضَضَعَة & $\begin{array}{l}\text { Aktualisasi, } \\
\text { modernisasi }\end{array}$ & عصرنة \\
\hline Sosialisasi & جَتْنَعَة & Formalisasi & صَوْرَنَة \\
\hline Kristalisasi & بلورة & Sekularisasi & عَلْمَنَة \\
\hline
\end{tabular}

\section{Masa Depan Leksikografi Arab di Indonesia}

Menurut penulis, leksikografi Arab di Indonesia memiliki masa depan yang prospektif sekaligus penuh tantangan, baik dilihat dari segi akademik maupun non-akademik, misalnya ekonomi dan bisnis. Ada beberapa alasan menarik yang memperkuat pendapt ini. Pertama, kebutuhan siswa, mahasiswa, guru, dosen, pegiat, dan peminat kajian bahasa Arab ke depan tampaknya cenderung semakin meningkat. Salah satu bukti nyata yang dapat ditunjukkan adalah semakin banyaknya Prodi PBA berbasis pesantren, mulai bermunculan Magister dan Program Doktor PBA di sebagian UIN dan IAIN di tanah air. Eksistensi IMLA (Ittihhād Mudarrisī al- 


\section{Arabi : Journal of Arabic Studies}

Lughah al-'Arabiyyah, Ikatan Pengajar Bahasa Arab) se-Indonesia yang berbasis di perguruan tinggi negeri dan swasta (baik di bawah pembinaan Kemenristek Dikti maupun Diktis Kemenag), madrasah dan pesantren berkontribusi sangat signifikan dalam menggeliatkan kajian, penelitian, publikasi, seminar bahasa Arab, baik nasional maupun internasional.

Kedua, meskipun digitalisasi berbagai hal, termasuk produk keilmuan semakin pesat dan cepat, tetapi kamus sebagai produk leksikografi tetap menjadi bagian penting dari sumber belajar bahasa sekaligus referensi kajian bahasa Arab. Selama bahasa Arab masih dikaji oleh siapapun, maka kebutuhan terhadap kamus yang lebih modern, kontekstual, dan komprehensif menjadi semakin dibutuhkan. KMY dipandang tetap relevan digunakan, meskipun perlu direvisi, dimutakhirkan, dan dikontekstualisasikan.

Ketiga, kamus bahasa Arab-Indonesia dan sebaliknya (Indonesia-Arab) yang diprediksi sangat dibutuhkan oleh kalangan pelajar, mahasiswa dan peminat kajian bahasa Arab adalah kamus kontekstual, diksi dan variasi pilihan padanan kata yang diberikan akurat dan aktual. Kamus bahasa Arab masa depan adalah juga kamus tematik yang praktis dan disertai konteks penggunaan kosakata dalam kalimat informatif (jumlah mufidah) secara menarik dan inspiratif. Contoh pemakaian kata "فصنل" dalam berbagai konteksnya tersebut, boleh jadi, cukup menggugah daya tarik dan motivasi belajar bahasa Arab.

\begin{tabular}{|c|c|c|}
\hline الترجمة الإندونيسية & استعمال لفظ "فصل" في سياقاته المختلفة & 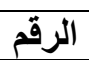 \\
\hline Bagian, bab kelima & قرأت الفصل الخامس من كتاب "العربية بين يديك". & 1 \\
\hline Musim paling indah & إن الربيع هو أجمل فصل من فصول السنة. & $r$ \\
\hline Semester pertama & إننا الآن في الفصل الأول من هذا العام الدراسي. & $r$ \\
\hline Babak kedua & شاهدنا الفصل الثانى من المسرحية. & $\varepsilon$ \\
\hline SK PHK & يستلم العامل قرار الفصل من العمل. & 0 \\
\hline $\begin{array}{l}\text { Sungguh, (al-Qur'an) itu } \\
\text { benar-benar firman pemisah } \\
\text { (antara yang hak dan yang } \\
\text { batil), dan (al-Qur'an) itu } \\
\text { bukanlah sendagurauan. (QS } \\
\text { at-Thariq [86]: 13-14) }\end{array}$ & إنه لقول فصل. وما هو بالهزل. & 7 \\
\hline $\begin{array}{l}\text { Sungguh, hari keputusan } \\
\text { adalah suatu waktu yang telah } \\
\text { ditetapkan (QS an-Naba' [78]: } \\
\text { 17) }\end{array}$ & إن يوم الفصل كان ميقاتا. & $V$ \\
\hline
\end{tabular}

Keempat, kamus Indonesia-Arab yang sejauh ini baru diwakili oleh Kamus al-Kalah, alBisyn̄, dan al-'Ashn̄ belum sepenuhnya memberikan konteks penggunaan kata Indonesia dengan padanan atau terjemahan bahasa Arab yang tepat dan membantu melatih penggunanya memiliki dzauq lughawi (apresiasi dan cita rasa bahasa) yang tepat dan tidak lagi "terinterferensi" oleh bahasa ibu. Karena itu, berdasarkan pengalaman penulis mengampu mata kuliah tarjamah Indonesia-Arab, contoh-contoh berikut jika dikamuskan secara kontekstual tidak hanya memberi pengayaan perbendaharaan bahasa Arab, melainkan juga dapat melatih dan membiasakan mereka dapat menulis insyāa, (komposisi) dan menejermahkan dengan baik, benar, kontekstual, dan berterima. 
Arabi : Journal of Arabic Studies

\begin{tabular}{|c|c|}
\hline $\begin{array}{c}\text { Penggunaan kata "bisa" dalam Aneka } \\
\text { konteks Kalimat }\end{array}$ & 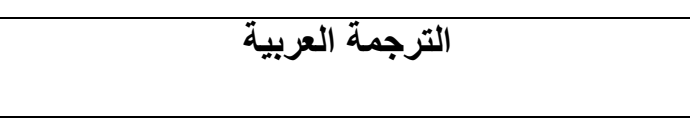 \\
\hline Air ini bisa diminum. & هذا الماء صالح للشرب. \\
\hline $\begin{array}{l}\text { Menulis merupakan kompetensi yang } \\
\text { bisa diamati. }\end{array}$ & الكتابة كفاية (كفاءة) قابلة للملاحظة. \\
\hline $\begin{array}{l}\text { Jika kita tidak memelihara kekuatan } \\
\text { bangunan bendungan (dam), maka dam } \\
\text { ini bisa ambrol/jebol/longsor. }\end{array}$ & لإنانهار لم نحافظ على قوة بناية السد، فإن السد عرضة \\
\hline $\begin{array}{l}\text { Kami pasti bisa menerjemahkan teks } \\
\text { berbahasa Indonesia ke dalam bahasa } \\
\text { Arab. }\end{array}$ & العربية. بالطبع على ترجمة النصوص الإندونيسية إلى \\
\hline $\begin{array}{l}\text { Para jamaah haji bisa berangkat ke } \\
\text { tanah suci melalui bandara } \\
\text { Internasional Soekarno-Hatta. }\end{array}$ & 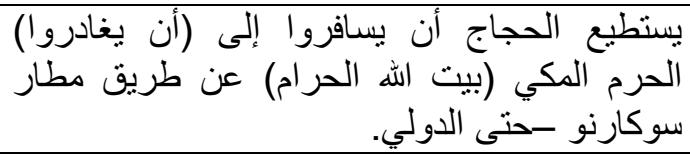 \\
\hline $\begin{array}{l}\text { Tujuan PBA adalah menyiapkan sarjana } \\
\text { yang bisa menjadi guru bahasa Arab } \\
\text { profesional di Madrasah. }\end{array}$ & 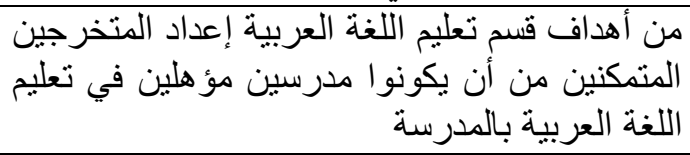 \\
\hline $\begin{array}{l}\text { Kalau bisa (boleh), saya mau } \\
\text { meminjam sebuah buku berjudul } 101 \\
\text { masalah cinta. }\end{array}$ & لو انو): مائة مشكلة أريد أن أستعلير كتابا عنوانه (يحمل \\
\hline $\begin{array}{l}\text { Maaf, hari ini saya tidak bisa masuk } \\
\text { kelas (mengikuti perkuliahan) karena } \\
\text { sakit. }\end{array}$ & مريضرة، أعتذر عن متابعة محاضرة اليوم لأني \\
\hline $\begin{array}{l}\text { Kitab-kitab karya manusia tidak bisa } \\
\text { menandingi keindahan bahasa al- } \\
\text { Qur'an. }\end{array}$ & القرآ أي كتاب ألفه الإنسان عاجز عن أن يأتي بمثل \\
\hline $\begin{array}{l}\text { Anda bisa datang ke kantor jurusan } \\
\text { PBA hari ini atau bisa juga besok pada } \\
\text { jam kerja. }\end{array}$ & تزوركن غدا مدة دور قام العمل. تعليم اللغة العربية هذا اليوم أو \\
\hline $\begin{array}{l}\text { Ah... kamu bisa aja menyebut tragedi } \\
\text { "Situ Gintung" sebagai "tsunami } \\
\text { lokal". }\end{array}$ & 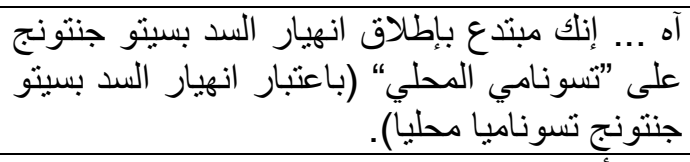 \\
\hline $\begin{array}{l}\text { Bisa ular itu sangat berbahaya terhadap } \\
\text { kesehatan manusia. }\end{array}$ & سم الأفعى مضر بصحة الإنسان. \\
\hline $\begin{array}{l}\text { tidak bisa dengan tangan, rubahlah } \\
\text { Ingkaran itu dengan lisanmu. }\end{array}$ & إن لم تسنطع بيدك، فلتغير منكر ا بلسانك. \\
\hline $\begin{array}{l}\text { Tujuan belajar muhāadaśah adalah } \\
\text { membisakan mahasiswa berbicara } \\
\text { dengan bahasa Arab secara lancar. }\end{array}$ & باللغة العداف تعلم المحادثة تمكين الطلاب من التكلم \\
\hline $\begin{array}{l}\text { Maaf, hari ini saya tidak bisa masuk } \\
\text { kelas (mengikuti perkuliahan) karena } \\
\text { sakit. }\end{array}$ & مريضرة، أعتذر عن متابعة محاضرة اليوم لأني \\
\hline $\begin{array}{l}\text { Kitab apapun karya manusia tidak bisa } \\
\text { menandingi keindahan bahasa al- } \\
\text { Qur'an. }\end{array}$ & القر آن جمالا أدبيا. ألفاب الإنسان عاجز عن أن يأتي بمثل \\
\hline
\end{tabular}

Dengan demikian, kamus Arab-Indonesia dan sebaliknya tetap menjadi kebutuhan akademik sebagai sumber belajar dan mengkaji bahasa Arab. Hanya saja, kamus yang ada, seperti KMY, perlu direvisi dan diperbarui setiap kali akan dicetak ulang, agar eksistensi kamus itu tetap 


\section{Arabi : Journal of Arabic Studies}

kontekstual, baik dari segi konten dan kasus maupun dari segi penggunaan kosakatanya dalam kalimat yang menarik dan menggugah penggunanya untuk mengembangkan keterampilan berbahasa Arab.

\section{Simpulan}

Sebagai karya leksikografis, Kamus Mahmud Yunus (KMY) tidak luput kritik baik segi metodologi penyusunannya maupun konten dan penerjemahannya. Namun demikian, kamus ini patut diapresiasi sebagai sebuah karya leksikografis rintisan yang tujuan utamanya adalah untuk memfasilitasi para pembelajar dan pengkaji bahasa Arab. Secara sosiologis, saat kamus ini disusun para pelajar dan pengkaji bahasa Arab dalam posisi menemui kesulitan tersendiri untuk mendapatkan kamus sejenis.

Dalam peta leksikografi, kamus Mahmud Yunus dapat dikategorikan sebagai kamus dwibahasa yang menginspirasi para leksikografer generasi sesudahnya untuk menyusun dan mempublikasikan kamus yang lebih mutakhir dan kontemporer. Dalam pemetaan leksikografi Arab di Indonesia, KMY dapat dikategorikan sebagai kamus dwibahasa yang menganut sistem şarfi dan bersistematika alfabetis, meskipun dalam beberapa entrinya tidak konsisten. Kamus ini juga tergolong perpaduan antara kamus biasa atau kamus umum dengan kamus bergambar, karena kamus dilengkapi dengan gambar-gambar yang disadur dari al-Munjid.

Kamus ini diprediksi masih akan tetap laku di pasaran dan diminati para penggunanya, terutama bagi para pemula. Akan tetapi, kamus ini menjadi lebih berbobot dan bernuansa linguistik modern, jika direvisi, dimutakhirkan, dan dikontekstualisasikan. Bahkan jika direvisi dan dimodernisasi lalu diprogram dalam aplikasi teknologi untuk dapat diunduh dalam ponsel berbasis android, maka eksistensi KMY akan semakin mendunia. Namun, usaha merevisi dan memutakhirkan entri dan diksi secara semantik maupun leksikografis bukan persoalan mudah, karena harus mendapat izin dari ahli warisnya, mengingat kamus ini sudah menjadi "warisan keluarga" dan sudah menjadi "klasik" dalam peta perkembangan leksikografi Arab di Indonesia. Oleh karena itu, kerja leksikografis Arab ke depan perlu diorientasikan kepada kamus istilah atau tematik sesuai dengan bidang ilmu yang berkembang, dengan pendekatan kontekstual, praktis, dan komprehensif.[]

\section{Daftar Rujukan}

Abdul Chaer. 2007. Leksikologi dan Leksikografi Indonesia. Jakarta: Rineka Cipta.

Abdullah, Hifni Daulah dan Nur Azlina binti Abdullah. 2012. "al-Māddah al-Mu'jamiyyah fi alMa'ājim al-‘Arabiyyah al-Mālayuwiyyah aś-Śnnāiyyah: Dirāsah Tahlīliyyah”. Majallah adDirāsāt al-Lughawiyyah wa al-Adabiyyah, IIUM.

Abd at-Tawwāb, Ramadhān. 1987. Fușūl fi Fiqh al- 'Arabiyyah. Kairo: Maktabah al-Khānijī.

Abdul Wahab, Muhbib. 2008. Epistemologi dan Metodologi Pembelajaran Bahasa Arab, Jakarta: UIN Jakarta Press.

Abdul Wahab, Muhbib. 2009. "Prof. Dr. Bustami A. Gani: Perintis Studi Islam di UIN", dalam Hamid Nasuhi (Ed.), Dari Ciputat, Cairo hingga Columbia: UIN Jakarta Menembus Masyarakt Global, Jakarta: UIN Jakarta Press.

'Akkāwī, Rihāa Khudhar. 1993. Mawsū'ah 'Abāqirat al-Islām fi al-Nahwwi wa al-Lughah wa alFiqh, Beirūt: Dār al-Fikr al-'Arabī.

al-'Āyid, Ahmad, 2003. al-Mu'jam al- 'Arabī al-Asāsī. Rabath: ISESCO.

Anīs, Ibrāhīm, dkk, 1972. al-Mu'jam al-Wasìth, Kairo: Majma' al-Lughah al-'Arabiyyah al-Qāhiri. 
Arif, Armai. 2009. "Prof. Dr. Mahmud Yunus: Perintis Jalan Menuju Terbentuknya UIN Syarif Hidayatullah Jakarta"; dalam Hamid Nasuhi (Ed.), Dari Ciputat, Cairo hingga Columbia: UIN Jakarta Menembus Masyarakt Global, Jakarta: UIN Jakarta Press.

Baharun, Hasan Ahmad. 1980. Majmū' 'àt 'Așriyyah fi al-Lughah al-'Arabiyyah. Bangil: Dār asSaqqāf.

ad-Dāyah, Muhammad Ridhwān. 1999. al-Maktabah al-'Arabiyyah wa Manhaj al-Bạhś, Damaskus: Dār al-Fikr al-Mu'āşir.

Fiddaroini, Saidun, "Kamus Indonesia-Arab dan Arab-Indonessia: Telaah LinguistikLeksikografik", dalam http://digilib.sunan-ampel.ac.id/gdl, diakses pada 20 Juni 2016.

al-Fiq̄ī, Şubh̄ī Ibrāhīm. 'Ilm al-Lughah an-Nașşi baina an-Nazhariyyah wa at-Tathbīq. Kairo: Dār Qubā'.

Halabī, Sāmir, "Dār al-'Ulūm: Masīrah Qarn min al-Tanwīr”, diakses dari http://WWW.alhandasa.net/, pada 12 Juni 2012.

Hassān, Tammām. 1998. al-Lughah al-'Arabiyyah: Ma’nāhā wa Mabnāhā, Kairo: 'Ālam al-Kutub, Cet. III.

Hassān, Tammām.2007. Ijtihā dāt Lughawiyyah. Kairo: 'Ālam al-Kutub.

Hijāzi, Mahmūū Fahmī. 1993. al-Baḩś al-Lughaw̄, Kairo: Maktabah Gharīb, 1993.

Hutari, Rina. 2011. "Manhaj Kitābat Qāmūs Arabi-Indunisi li Mahmud Yunus: Dirāsah Tahlīiliyyah Washfiyyah”. Bahś Ilmi. Jakarta: Fakultas Adab dan Humaniora UIN Syarif Hidayatullah.

Ibrāhīm, Rajab 'Abd al-Jawād. 2001. Dirāsah fi ad-Dalālah wa al-Ma'ājim. Kairo: Dār Gharīb.

an-Nasywān, Aḥmad bin Muhammad. "Ittijāhāt Muta'allimī al-Lughah al-'Arabiyyah Ghair anNāthiqīna biha Nahwa Isti'māl al-Mu'jam. Majallah Jāmi'ah Umm al-Qurā li 'Uhùm asSyan̄' ah wa al-Lughah al-'Arabiyyah wa Ā dabihā. Edisi 18, Ramadhān 1427 H.

Nuryani. 2015. “'Ilm al-Mu'jam: an-Nazhariyyāt wa at-Tathbiq”. Majmū 'ah Buhūśs (Prosiding) alLughah al- 'Arabiyyah Asās as-Śaqā fah al-Insāniyyah, UIN Maliki Malang.

Qaddūr, Aḥmad Muhammad. 1999. Mabādi' al-Lisāniyyāt. Damaskus: Dār al-Fikr al-Mu'āşir.

Qaddūr, Aḥmad Muhammad. 2001. al-Lisāniyyāt wa Ā făq ad-Dars al-Lughaw̄̄. Damaskus: Dār alFikr al-Mu'āşir.

Qāsim, Riyādh Zakī. 1987. al-Mu'jam al-'Arabì: Buhn̄ts fi al-Māddah wa al-Manhaj wa alTathbīq. Beirut: Dār al-Ma’rifah.

al-Qāsimī, 'Alī. 1991. 'Ilm al-Lughah wa Şinā 'at al-Mu'jam. Riyādh: Jāmi' ah al-Malik Sa'ud.

ar-Rājih̄ī, Syarafuddin 'Alī, Fi 'Ilm al-Lughah 'inda al-'Arab wa Ra'yu 'Ilm al-Lughah al-Hadits, Alexandria: Dār al-Ma'rifah, 2002.

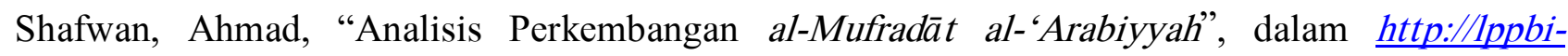
fiba.blogspot.com, diakses 20 Juni 2012.

as-Şarrāf, 'Alī Mahmūd. 2013. "Ușūl al-Mu'jam al-'Arabī”. al-Majallah al-'Urdunniyyah fi alLughah al-'Arabiyyah wa Ā dābihā. Jilid 9, Edisi 4, Desember.

Taufiqurrochman, R. 2014. Tașn̄̄f al-Ma'ājim al-'Arabiyyah wa Tathw̄iruhā fi Indonesia: Dirāsah Washfiyyah, Tahtiliyyah, Tathwīriyyah. Malang: UIN Maliki. 
Arabi : Journal of Arabic Studies

Titscher, Stefen, et.al. 2009. Metode Analisis Teks \& Wacana. Terjemahan dari Methods of Text and Discourse Analysis. Yogyakarta: Pustaka Pelajar.

at-Thanthāwī, Muhammad. 2002. Nasy'at al-Nahnwi wa Tān̄kh Asyhar al-Nuḥāt, Tahquīq Abū Muhammad 'Abd al-Rahmân ibn Muhammad ibn Ismâ'îl, Mekkah: Maktabah Ihyâ' al-Turāś al-Islāmī.

Ya'qūb, Emil Badī'. 1981. al-Ma'ājim al-Lughawiyyah al-'Arabiyyah. Beirut: Dār al-Śaqāfah alIslāmiyyah.

Yunus, Mahmud. 1990. Kamus 'Arabi-Indunisi, Jakarta: Hidakarya Agung. 